Review

\title{
Review of the history of the teaching of medicine in Arabic
}

B. Al-Kateb ${ }^{1}$

\section{Introduction and historical background}

When we review the history of the Arab Islamic civilization, we note that it inherited the legacy of the Greek civilization and took its place in the line of pioneering human civilizations. The Roman civilization. which immediately followed the Greek civilization and should have been its natural heir, did not leave behind it any cultural legacy and was no more than a link that followed the Greek epoch in the sequence of civilizations. This is because the Romans did not attach any importance to the translation of the Greek legacy into Latin. As for the Greek language, it declined and lost its influence following the appearance of the Roman state, and thus, as Bertrand Russell said, only a few people were left in Europe who could read Greek books.

The Arabs, however, studied Greek books and found them to contain considerable information and knowledge. They translated them, learned from them, added to them the new knowledge they originated and presented a rich legacy to human civilization, although theirs was a civilization professing Islam as its religion and using Arabic as its language of expression. When cultural leadership passed to the Europeans, they established a Christian civiliza- tion which initially used Latin and then later used the local languages.

It may be possible to compare the attitude of the Romans to the Greek civilization to that of the Turks as regards the Arab Islamic civilization. Just as the Romans did not care to translate the Greek legacy into Latin, the Turks did not translate the Arab Islamic legacy into Turkish. Furthermore, they neither learned Arabic nor did they adopt it as the official language of the Ottoman Administration, although their empire was regarded as an extension of the Arab Ahbasid state, passed to them after the battle of Merj Dabek against Konsoua AlGhoury in 1517, the defeat of the Mameluke Touman Bcy in Egypt, the fall of IIijaz, and the passage of the caliphate to the Ottoman Sultan Selim the First (Ya'ouz Selim).

It is true that the Ottomans rounded up the dispersed Islamic people and brought Islam to the gates of Vienna. However, they did not translate the Arab Islamic legacy into their official language, Turkish. They may not have had sufficient time to achieve this end as they were, on the one hand, engrossed in incessant warfare and on the oth$\mathrm{er}$, as Stanford Shaw said, interested only in poetry and prose. Had they adopted the language of the Koran as the official language of their empire, they would have been able

${ }^{1}$ Faculty of Medicine, University of Aleppo, Aleppo, Syrian Arab Republic.

This article was first published in Arabic in Vol. 1 No. 2 of the Eastern Mediterranean health journal.

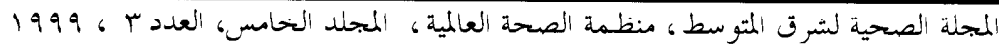


to form an uninterrupted sequence and might have founded a rich civilization using the treasures, achievements and findings of the previous epoch, particularly in the field of science.

Although the Europeans could not learn about the ancient Greek civilization through the Romans and Latin, they were able, through the Arab schools of Sicily and Andalusia, to translate both what the Arabs had inherited from the Greeks and what they had originated into Latin, the language of the clergy, the nobles and the educated rich at the time.

However, with the beginning of the Renaissance in Europe, class monopoly of learning began to decline, particularly as authors began to write in their local languages, starting with Dante and the Divine Comedy, and later Machiavelli and The Prince, both of which were written in Italian. Thus, local languages emerged as important means of communicating knowledge to all classes of the population, a step which marked the heginning of the scientific revolution during the Renaissance in Europe.

This suggests that the rise of a civilization among a certain population is associated with the dissemination of information and knowledge in the language of the population in question. It also shows that when the language of learning in a community differs from the language spoken by the community, the result is cultural retardation and underdevelopment. This was the case of the Romans who did not assimilate the Greek civilization because of linguistic restrictions, and the case of the Ottoman Turks who did not benefit from the Arab Islamic civilization by translating it into their language or by adopting Arabic as thcir official language and the vehicle of education, which would thereby have ensured the continuity of the civilization.
Napoleon Bonaparte's expedition to Egypt, although of short duration, has been regarded as the start of a new era in Egypt. The retreat of the French army was first and foremost due to British military and political supremacy. It is worth noting in this respect that the British/French conflict over the Middle East delayed the fall of the Ottoman empire by approximately one hundred years. When Britain and France reached an understanding over the division of the Turkish empire, including the Arab countries, in accordance with the Sykes-Picot Agreement and the provisions of the 1923 Cairo Conference, Western imperialism began to impose its colonization plans on this strategic part of the world. Nevertheless, the fragmentation and division of the Arab countries, which took place after the First World War, had been delayed by approximately one century.

During the 19th century, the talented and peerless Muhammad Ali Pacha was able to establish a strong modern state in Egypt, although he was an expatriate from Kavala, Greece and did not speak the national language. However, he shrewdly made Arabic the official language of education in Egypt, although Turkish was the language he spoke and was the official language of the empire that owcd allegiance to the Sultan, the Caliph of Muslims.

Muhammad Ali awarded fellowships to Egyptian youths to study in France. When they returned home, they taught in the high schools inaugurated by Muhammad Ali using Arabic, the national language of the community in which they lived, not French, the language in which they had studied nor Turkish, the official language of the empire of which they were part.

The Abu Za'abal School for Medicine and Pharmacy was one of the higher education colleges founded by Muhammad Ali. It was established in $1826 / 1827$ and was 
transferred to Al-Kasr Al-Eini in Cairo in 1837. Teaching was conducted in Arabic and did not change to English until 1887, several years after the British had entered Egypt and imposed their protectorate on it.

Higher education in Arabic was not restricted to the teaching of medicine and pharmacy but covered military and civil disciplines as well. This policy of teaching in the national language, carried out during the reign of Muhammad Ali, quickly yielded results. Knowledge spread and Egypt began to take the form of a modern contemporary state that was a threat to the Ottoman empire to which it belonged.

Political and military supremacy has always been the consequence of scientific and technological progress and the economic boom that accompanies it. On the other hand, scientific progress cannot be achieved unless modern knowledge and information arc diffused to the largest number of people in the country, and this cannot be achieved unless knowledge is disseminated in the national language.

When the foreign powers seeking to fragment and divide the Ottoman empire noted the emergence of a strong, modern state within the old empire, they hastened to conspire against it. The Ottoman ruler, seeing his power threatened by one of his subordinates, asked the Europeans for assistance. They agreed to support him, not because they wished to preserve the Ottoman empire, but for fear that the Muslim Arab East would produce a state that would impede and hamper their plans to eliminate the Ottoman empire and the Islamic caliphate. Thus, conspiracies against Muhammad Ali continued, until the day came when his successors drowned the country in debts. The British hurried to occupy Egypt in 1882 and changed it into a protectorate with nothing to link it to the Turkish Sultan except a slight spiritual relationship. The first thing they sought to do was to contain the rapid scientific progress being made at the time. Education began to be conducted in English rather than in Arabic in all disciplines, including medicine.

\section{Higher education in the northern region (Syrian Arab Republic, Lebanon and Palestine)}

The situation in the northern region was different from that in Egypt. No leader comparable to Muhammad Ali had appeared there and accordingly no scientific progress, similar to that which took place in Egypt, had been achieved. In the second half of the 19th century, however, an American evangelical mission came to Lebanon and founded the American School in one of the Lebanese villages (Obaya). The school was then moved to Beirut and became known as the American College. The teaching of medicine began in this college in 1867.

The American Evangelical Mission selected another site in the midst of the Ottoman empire. It established in the city of Eintab, a hospital that still stands and is known as the American Hospital, and a school of medicine. However, teaching stopped in the school three years after its inauguration.

As for the American College in Beirut, it has continued to this day and remains an important cultural landmark in the Middle East. It is curious that the teaching of medicine at the American College in Beirut was conducted at first in Arabic. The American professors who taught at the College were obliged to learn Arabic from renowned and eminent tutors such as Master Botros AlBustani and Sheik Nasseef Al-Yazgy. The 
best known of the American professors was Dr Cornelius Van Dyke who taught chemistry and pathology in Arabic. He also wrote books in Arabic, most important of which were his books entitled Pathology and $\mathrm{Al}$ naqsh fi al hagar (Engraving on stone), which was published in nine small volumes covering several disciplines, such as chemistry, physics and botany.

Amongst the well known professors at the American College in Beirut was Dr George Post who taught surgery and botany, as well as medical subjects. He wrote several books in Arabic on the disciplines he taught, such as Al-misbah al-waddah $\mathrm{fi}$ sina'at al-garaha (Illuminating light on surgery), a book on pharmacology, books on medicinal substances, principles of anatomy and hygiene, physiology, as well as a book entitled Botany and another entitled Zoology. A third distinguished professor was Dr John Wartabet who taught in Arabic at the Faculty of Medicine and also wrote books in Arabic on anatomy, physiology and hygiene.

However, teaching in Arabic which began at the American College in Beirut did not last long. Although no accurate details nor dates on the shift to the use of English are available, it is believed to have happened after the fall of the Ottoman empire and the arrival of the French and British in the region.

Modern history provides another example of foreign teachers who were obliged to teach in the language of the country in which they sought refuge. This was the case of a group of German professors who had fled to Turkey in 1933 from the Nazi rule in Germany; it included eminent specialists such as Nissen in surgery, Shwartz in pathology, Winterstein in physiology, Frank in internal medicine, Max Clara in embryology and Stary in biochemistry. These political refugees helped make the University of Istanbul, previously called "The House of Arts", a modern contemporary university. At first, they lectured in German with simultaneous translation into Turkish; later they were forced to learn and lecture in Turkish. The author himself was privileged to benefit from their interesting Turkish lectures and to study their Turkish textbooks.

\section{Origin and development of higher medical education in Syria}

The Ottoman rule recognized the need to establish in Syria higher colleges and institutes in which students could enrol after secondary school education. It also took into consideration the difficulties and costs involved in sending students to continue higher studies in Istanbul. Accordingly, a medical institute and some military institutes were inaugurated in Damascus. Taking into account the role that could be played by missions such as the St. Joseph Monastic Order and the American Evangelical Mission, the administration was motivated to establish the Ottoman Faculty of Medicine in Damascus in 1901. Teaching in Turkish began in this Faculty in 1903 and continued for approximately ten years. The Faculty remained in Damascus until 1913 when it was moved to Beirut and became known as the "Ottoman Medical". Examinations were held only in the presence of professors delegated by the Faculty of Medicine of Istanbul. During the First World War, and because France at that time formed part of the coalition that opposed the Ottoman state, St. Joseph College in Beirut closed down and the Ottoman Medical took its place. In 1918, the war ended and the Ottoman statc and its allics werc defeated and withdrew from Syria and Leb- 
anon. St. Joseph College was re-inaugurated and the Ottoman Medical closed. Its students were mostly from Syria, Lebanon, Palestine and Jordan and they were enrolled in various grades and classes of medicine and pharmacy.

The Arab Revolution Army led by Sharif Faisal (who later became King Faisal the First, King of Syria and later of Iraq) entered Damascus with the armies of the Allies led by the British General Allenby. The first Arab government was then established in Damascus after four centuries of Ottoman rule in the Arab countries.

Despite the critical political and economic conditions, the prevailing feeling of instability and the uncertain future that this new state was facing, a group of Syrian scholars, assisted by some teachers of the Ottoman Medical and some civil and military physicians and pharmacists, called for the revival of the Ottoman Medical for medicine and pharmacy under the name of The Arab Medical Institute and the establishment of a law institute.

These institutes formed the beginning of the Syrian University in Damascus. It brought together the undecided and unsettled students of the Ottoman Medical, and it was decided in the academic year 1918 1919 that teaching in this new university would be conducted in Arabic. Enthusiasm was kindled and excitement was intense regarding the rise of a unified Arab state that would include Hijaz, Najd, Iraq and the whole of the northern countries. In addition, there was a keen interest in reviving Arabic and eliminating all traces of Turkish in the new Arab nation.

In this nationalistic atmosphere, teaching began in Arabic at the Arab Medical Institute and the Law Institute. Amongst the first students who enrolled in the Arab Medical Institute were Dr Hosni Sabah and Dr Shawkat Al-Shatty who studied medi- cine and Doctor Ahmed Safa Al-Kateb who studied pharmacy, may God have mercy upon their souls.

As for the teachers and professors, they were all physicians and pharmacists who had studied in Turkish, graduated from Ottoman schools and faculties and who would have preferred to lecture in Turkish, at least for a transitionary period. However, they were all engaged to teach in Arabic, which was not easy, and compiling the nccessary technical terminology was then a serious problem. The Ottomans, when compiling scientific terms, had made use of Arabic terms and given them Turkish forms. Indeed, there were a number of Arab teachers at the University of Istanbul who, when translating a term taken from a foreign language (French, German, English or Latin), and not finding an equivalent for it in Turkish, would have recourse to Arabic. This was relatively easy as Turkish continued to be written in Arabic script until 1928, when Mostafa Kamel Attaturk decreed that it was to be written in Roman script.

Furthermore, Turkish at the time of the Ottomans was full of Arabic and Persian words. Thus, giving Arabic equivalents to scientific terms was acceptable to the Turkish ear and did not sound discordant. Renowned amongst the Arab teachers at the University of Istanbul were Doctor $\mathrm{Na}$ 'oum Al-Rami, Professor of Anatomy, whose home town was Falouga in Lebanon and Doctor Bassil Na'oum Shashati, Professor of Biochemistry, who came from a well known, old family in Aleppo. Thus, it was easy for the teachers of the Arab Medical Institute to use a large number of the Turkish scientific terms after turning them back into their original Arabic form.

These professors also turned to books of medicine written in Arabic or translated into Arabic and published in Egypt or Beirut. When they did not find a suitable Arabic

المجلة الصحية لشرق المتوسط، منظمة الصحة العالمية، المجلد الخامس، العدد ب ، 1999 
term in use, or felt that the term currently in use was inadequate, they referred to the ancient Arab books. Later, they began to write books in Arabic, relying on their linguistic proficiency and medical knowledge. At the end of these books they also added a list of the medical terms used and their equivalents in other foreign languages.

People may wonder why medicine was not taught in French in Syria, as was the case at the Faculty of Medicine of Baghdad, instituted in 1927, where teaching was conducted in English throughout all the years of study. However, the situation in Syria was different. The Arab Medical Institute was founded in Damascus in 1918, immediately after the withdrawal of the Turks and the entry of the Arab army which raised the Arab banner and presaged the establishment of an independent unified Arab state. Although the political situation in Syria was not yet clear, the government which assumed responsibility was an Arab government headed by Prince Faisal and based in Damascus. From this city, the Prince went to the Versailles Peace Conference, representing his father Sharif Hussein Ben Ali. He earnestly urged those to whom he had been recently allied to fulfil the promises they had made regarding the establishment of a unified Arab state. Conditions were not encouraging inside Syria, but, although the internal situation was unstable and political uneasiness prevailed, power was in the hands of the nationals, and the governments which succeeded each other for two years were all local governments. This state of affairs continued until the independence of Syria was declared and Prince Faisal was crowned King on 8 March 1920. France only entered Syria as a mandatory power after the battle of Maissalone on 24 July 1920, which led to the downfall of the first Arab parliamentary democratic rule after four centuries of Ottoman occupation.
Thus, when France occupied Syria, two higher education institutes were in existence, namely the Arab Medical Institute and the Law Institute. Teaching was conducted in the national language by pioneering professors who believed in the idea of teaching in Arabic, were enthusiastic about it and were willing to deal with any difficulties or problems that ensued. France tried several times to change the language of teaching to French but those attempts were resisted by the responsible authorities at the University, and even by the governments ruling under the French mandatory power.

It must have been difficult for those pioneering professors, who had done all their studies in Turkish, to teach in Arabic and equally difficult for the students to learn without textbooks available; most probably the teachers resorted to dictating. However, within a few years, there were textbooks in all the disciplines taught.

Distinguished amongst the scholars in the field of arabicization of medical teaching were Dr Murshid Khater, who wrote a six-volume textbook on surgery, then abridged it into two volumes, Dr Ahmed Hamdy Al- Khayat who wrote a textbook on bacteriology, Dr Muhammad Gameel Al-Khany, who authored a textbook on physics, Dr Hosni Sabah, who remained for a long time President of the Arabic Language Academy and wrote a seven-volume textbook on internal medicine, annexing to each volume the French and English terms equivalent to the Arabic terms used, and $\mathrm{Dr}$ Salah Eddin Al-Kawakby, who was a professor at the Faculty of Pharmacy and was responsible for the arabicization of numcrous terms in the fields of pharmacy and chemistry.

In 1955, a committee was formed of $\mathrm{Dr}$ Khater, Dr Khayat and Dr Kawakby; it was authorized by Clairville, the author of the multilingual Medical dictionary, to compile 
a copy of it in both French and Arabic. Thus, a dictionary of medical terms comprising 14500 terms was published in 1956, printed at the Syrian University Press.

Since 1900, several dictionaries have been issued, the most recent which was the Unified medical dictionary published by the Arab Medical Union. The first edition appeared in 1973 and the last, revised and printed in Switzerland, appeared in 1983. It includes Arabic terms and their equivalents in both English and French and is probably the most widely used Arabic medical dictionary, characterized by accuracy and precision. No one can claim that it is complete or perfect; arguments continue as regards some of the Arabic terms included and serious ideas for its improvement are being put forward by parties concerned with medical education arabicization. However, there is no doubt that it is an accepted dictionary, to be referred to and adhered to when writing scientific research or a medical textbook in Arabic.

The experience of the University of Damascus in the field of teaching medical sciences in Arabic is considered a pilot experience. The University has been providing higher education to students from Syria and neighbouring countries, such as Jordan, Iraq, Lebanon and Palestine since its inception. Generations of competent physicians, pharmacists and dentists have graduated from the University. They have all studied in Arabic and have been successful in their fields. Arabic did not prevent them from pursuing further studies in their field of specialization in Europe and North Ameri- ca. They may have met with some difficulties at first, but they were able to surmount them, using determination, patience and perseverence. In this respect, two points need to be highlighted.

First, the limited number of students enabled good practical and scientific training and made direct contact with professors possible and allowed the students to benefit from their expertise. This was particularly the case with those students who, at the end of their fifth year, remained for two years as residents at the university tcaching hospital. The second point is that Syrian students were proficient in French. This applied. both to those who undertook school education in governmental schools and those who studied in French schools. This important and catalytic factor enabled students to refer to foreign textbooks and travel to French-speaking countries to conduct further specialized studies. As for the students of neighbouring countries studying in Damascus, they were mostly from Iraq, Jordan and Palestine. These were fluent in English as their countries were under the British Mandate, and it was also possible for them to conduct specialized studies in English-speaking countries.

Following the Second World War, and the withdrawal of the foreign armies from Syria, the organization of the University of Syria was restructured. New faculties were established and old ones were reorganized and updated, such as the faculties of medicine, dentistry and pharmacy. Teaching has continued to be conducted in Arabic in all the faculties of the University of Damascus. 